\title{
The Evaluation Research of Corporate Brand Competitiveness in Web2.0 Environment
}

\author{
Liu Biaowen*
}

Vocational and Technical College of Jiangxi University of Finance and Economics, Nanchang, Jiangxi, 330013, China

\begin{abstract}
Internet, the Internet has deep into every corner in people's lives. At the same time, the Internet itself gradually completed to the transition of the maker of the network information era of Web2.0. Chinese companies, whatever Internet companies, or offline industrial enterprises, both seek the development opportunities in the network environment and social environment, and promote the competitiveness of the enterprise's brand combining with the network environment. Therefore, under the web environment, the corporate brand competitiveness become a new topic of research.
\end{abstract}

Keywords: Brand competitiveness, Evaluation system, Evaluation method, web2.0.

\section{THE WEB2.0 ENVIRONMENT}

Based on the definition of baidu encyclopedia, Web 2.0 is a new type of Internet applications in contrast with Web1.0. The main characteristic of Web1.0 is that the user through a browser access to information. Web2.0 pay more attention to the interaction of the user, the user is not only the content of your visitors, but also is the site content. The so-called content maker is said on the Internet, each user is no longer merely the readers of the Internet, it has also become the author of the Internet; On the model from a mere "read" to "write" and "construct" development; By passively accepting the Internet information to take the initiative to create the Internet development, thus more human. The internet of Web2.0 mode has the following marked characteristics: (1) users to share. In the Web 2.0 mode, the user are not restricted by time and place to share ideas. The user can get the information who need and can also release their point of view. (2) information aggregation. Information on the network to accumulate, not lost. (3) the community with interest as the aggregation point. Gathered under the mode of Web 2.0, is interested in some or certain problem. (4) open platform, active users. The platform is open for users, and users maintain relatively high loyalty because of interest, they will be actively involved.

From early BBS to as famous Facebook of SNS social networking, and to today's popular micro-blog, "We Media" can be summed up the biggest characteristic of the Web2.0 network environment. Put Web2.0 phenomenon in the development of science and technology and social change of view to see, the web can be said to be the development of network information technology revolution, and the resulting future-oriented, people-oriented innovation model in the field of the Internet, is a professional web to all users to participate in the innovation of the netting vivid annotation of democratization. Since the media features of Web2.0 constitutes the realistic environment for the development of Chinese enterprise culture in the new period, any enterprises ignore the reality of the environment that is very difficult to get development in the new environment.

\section{THE CORPORATE BRAND COMPETITIVENESS AND ITS CONSTRUCTION OF THE EVALUATION SYSTEM}

\subsection{The Connotation of Brand Competitiveness}

Zhang Shixian (1997) argued that the corporate brand competitiveness was mainly manifested in two aspects: the market share and value creation ability, brand value is the manifestation of brand competitiveness. Whether a brand have competitiveness depends on its relative advantages of market share, whether it have certain ability of premium.

Ji Liuxiang (2002) pointed out: "the corporate brand competitiveness broadly cover industrial competitiveness, regional, national or international level on the integration and unification of the brand image; in a narrow sense, it refers to the brand in a competitive market have to continue to more effectively than other brands to gain market recognition and support of the overall image quality, it is about the corporate strategy, management mode, the technical route, the corporate culture and information to support effective integration of the image elements ".

Li Guangdou (2004) defined the brand competitiveness as that some brand have bigger influence, higher market share, higher added value, longer life cycle compared with similar products, the deep reason is refers to the corporate brand possess unique ability that differ or is ahead of other 
competitors, can show brand intrinsic quality, technology, performance, and perfect service in market competition, can cause the brand association and promote their purchasing behavior of consumers. Xu Jinan thought that brand competitiveness refereed that the enterprise made the brand better than rival brands to meet the needs of consumers through the effective allocation and use of resources, thereby expanding market share, make big profits compared with the competition in the market competition of brand.

In conclusion, Brand competitiveness refers to the ability that the enterprise possess the brand external image and internal quality, technology, performance, and can continually differ or ahead of other competitors, make its products and services better and faster than its competitors to meet consumer demand, make the enterprise gain competitive advantage and provide value for the enterprise profit. It is the core competitiveness of the enterprises in the market of materialization and commercialization performance. A strong brand can not only improve brand competitive brand product sales, also can improve the brand value of the asset. Brand competitiveness is the enterprise that gradually accumulate in the long-term brand management practice and integrate all skills to form in the corporate brand management, it is the deep reason that some brand have bigger influence, higher market share, higher added value, longer life cycle compared with similar products.

Scholars who defined the angle of the brand competitiveness and emphasis was different. The former embarks from the index of the brand competitiveness of market power to define the connotation of brand competitiveness, secondly from image to define, and definition is given from the perspective of inherent attributes in the angle of the brand equity, finally from the perspective about satisfying the demand of consumer. In short, the brand competitiveness is characterized that an enterprise has a higher assets value, better corporate and product image, higher market share and market sales than its competitors.

\subsection{The characteristics of the Brand Competitiveness}

Brand competence is formed by various factors that superpose and penetrate mutually. Its characteristics displays in:

(1) The brand competitiveness have irreplaceable differentiation ability, it is the enterprise's unique ability, and not easy to even unable to imitate by competitors. Brand is one of the most important symbol that the corporate product or service differs from other similar products, it is no alternative, is unique. The stronger the brand competitiveness, the stronger the its exclusive exclusiveness.

(2) The brand competitiveness has the sustained profitability of enterprises and brand premium power to get excess profits. The brand endows the products with intangible reputation values, the overflow of the reputation values is the source of a bigger power than the tangible assets. A strong brand with strong brand competitiveness, high-profile, big influence, thus can set high prices, make the products selling at a premium, get a much higher premium profits than the normal products.

(3) The brand competitiveness is the corporate longterm accumulated ability, which is deeply rooted in the enterprise, and has the characteristics of the continuous and the occasional. Brand competitiveness can create sustainable competitive advantage for enterprises, make the enterprise keep long-term initiative in the competition, and get more than the industry average return on investment.

(4) The brand competitiveness has the ability of constructing barriers to competition. If enterprises want to win in competition, to a large extent they depend on setting barriers for rivals successfully. Any business enterprise will face "new enterprises" and "substitute threat", which is the challenge of these basic competitive forces. While the brand competitiveness is relatively little touched compared to the corporate other resources.

(5) The brand competitiveness has the ability to strengthen customer brand loyalty, improve the ability of customers' satisfaction after purchase. When the competitive products emerge in the market, the brand loyalty can reduce the customers to try new branding efforts, so it is advantageous for the enterprise to win precious time for strategy adjustment.

(6) The brand competitiveness has the ability to enhance customer confidence and control the purchase risk. The strong brand can help customers to reduce purchase pressure, guide the customers' identification from the product transition to the brand, reduce the risk of the customers to purchase products or services.

\subsection{The Building of Brand Competitiveness Evaluation System}

Domestic scholars put forward a variety of evaluation index system from different angles on the research of the brand competitiveness evaluation, there are external and internal; quantitative and qualitative; directly related, indirect weak correlation, etc. This paper consider the web2.0 environment, which build the corporate brand competitiveness evaluation system from the brand marketing, brand management, brand development potential, brand relationship and brand website construction and so on in five aspects.

\subsubsection{Brand Market Ability}

The brand market ability is that the brand produce the ability of a leading opponent by comparing with the competitive brands in the market, it is external and dominant index system of the brand competition. Including four indicators, such as brand market share, the excess profit rate, brand awareness and brand global influence, among them, the brand market share and the excess profit rate is a quantitative index, the objective evaluation method can be used to evaluate; The brand awareness and brand influence 
in the world is qualitative indicators, the subjective evaluation method can be used.

\subsubsection{Brand Management Ability}

Brand management ability is an unique ability that forms in the process of corporate brand management activities, it is essential for the enterprise to shape a strong brand and improve brand competitiveness. Including brand communication, brand positioning, the technical innovation ability, brand quality management ability and brand culture management skills and the ability to network brand promotion, they are the internally and invisibly index system that reflect the enterprise, which can use the subjective evaluation method to evaluation.

\subsubsection{Brand Development Potential}

Brand development potential is gradually formed in the brand management activity, which is the ability that can contribute to long-term development of the brand and become a strong brand. Including the brand market growth rate, brand extension, brand expansion potential ability and brand reputation 4 index.

\subsubsection{Brand Relationship}

Brand relationship is the ability that the enterprises build and maintain the long-term good relations with customers, suppliers and partners and other stakeholders in the process of brand management, it is the foundation of the corporate brand to gain market recognition, but also the external support of brand competitiveness. Concrete can be divided into three indicators, such as the brand and customer relationship, brand and supplier relationships and brand with partnership.

\subsubsection{Brand Website Construction Ability}

Brand website construction ability refers that the enterprise use web2.0 network to set up the brand image, improve the visibility and influence of network brand, and induce the network users to produce good brand association

Table 1. The corporate brand competitiveness comprehensive evaluation system.

\begin{tabular}{|c|c|c|}
\hline Target layer A & Evaluation index (U) & Index content (Uij) \\
\hline \multirow{21}{*}{$\begin{array}{l}\text { The corporate comprehensive } \\
\text { evaluation system of brand } \\
\text { competitiveness }\end{array}$} & \multirow[t]{4}{*}{ Brand market capacity (U1) } & Market share (U11) \\
\hline & & The excess profit margins (U12) \\
\hline & & Brand awareness (U13) \\
\hline & & The global influence (U14) \\
\hline & \multirow[t]{6}{*}{ Brand management ability (U2) } & Brand communication ability (U21) \\
\hline & & Brand positioning capability (U22) \\
\hline & & Technology innovation ability (U23) \\
\hline & & Brand quality management capability (U24) \\
\hline & & Brand culture management capability (U25) \\
\hline & & Network brand promotion ability (U26) \\
\hline & \multirow[t]{4}{*}{ Brand development potential (U3) } & Brand market growth rate (U31) \\
\hline & & Brand extension potential (U32) \\
\hline & & Brand expansion ability (U33) \\
\hline & & Brand reputation (U34) \\
\hline & \multirow[t]{3}{*}{ Brand relationship (U4) } & The relationship between the customers and the brand (U41) \\
\hline & & Brand relationships with suppliers (U42) \\
\hline & & Brand relationship with the partners (U43) \\
\hline & \multirow[t]{4}{*}{ Brand website construction (U5) } & Brand image (U51) \\
\hline & & Brand rankings (U52) \\
\hline & & Search engine optimization (U53) \\
\hline & & Brand website content updates (U54) \\
\hline
\end{tabular}


so as to promote to purchase, it is an essentially index system for evaluating the brand competitiveness under the web2.0 environment. Including four indicator, such as brand image, brand rankings, search engine optimization and brand website content updates.

According to the above analysis, I established the comprehensive evaluation index system of enterprise brand competition (see Table 1).

\section{THE BRAND COMPETITIVENESS EVALUATION METHODS}

At present, scholars have a lot of methods to evaluate the brand competitiveness, both are based on the multi-index comprehensive evaluation. Mainly from the two steps, first of all, it is concluded the comprehensive evaluation of corporate competitiveness by means of mathematical statistics; And then comparing with the size of corporate competitiveness according to the comprehensive evaluation. The majority of studies are to choose the evaluation index through expert scoring method, to obtain quantitative indexes and qualitative indexes by the basic data and the questionnaire score respectively, to determine the weight by Delphi method or random, entropy method, the pairwise comparison method, analytic hierarchy process and so on.

The most commonly used evaluation methods are: (1) AH analytic hierarchy process (ahp). It is a combination of qualitative and quantitative systematic analysis method, it need less quantitative data information, but when we selected indicators that are excessive, data statistics will be very big, and it is difficult to determine the weight, the accurate calculation methods about the eigenvalue and eigenvector is more complex; (2) The fuzzy comprehensive evaluation method. This is a kind of fuzzy evaluation objects by means of fuzzy information to make a more scientific and reasonable quantitative evaluation, the result is a vector that contains rich information, but the computation is complex, the confirmation about the index weight is subjectivity, and when the index set is bigger, it is possible that the weight vector don't match with the fuzzy matrix $\mathrm{R}$ under the constraint that the weight vector and 1, leading to the final evaluation is likely to fail; (3) The factor analysis. This kind of evaluation method simplifies the system structure, explore the kernel of the system; (4) The osculating value method. This is a kind of method that based on the actual values of the evaluation index to constitute the most advantages and bad points, then computing the osculating value of the actual situation, according to the size of order of the osculating value to compare, the process of operation is simple in this method, the evaluation results is good and more objective, but using the method of equal-weight to approach different evaluation indexes can make the results appeared deviation in the process of the operation, but these deviations can be overcome through improving the osculating value method; (5) the BP neural network. It is a method to make a decision on an approximate, uncertain, even contradictions related knowledge environment through emulational experiment, to allow for a larger defect samples and distortion, to avoid the weight set and level of complicated calculation, to rule out the subjective influence and uncertainties, there are a lot of types of this method, it need to consider different model based on the characteristics of the investigative object, one of the most famous is the multilayer forward network training algorithm, but the algorithm exist some disadvantages, such as slow convergence speed and local extremum, but it still can solve these problems by improving; (6) Gray correlation analysis method. This is a kind of method to provide a quantitative measure for the developing tendency of a system, it is very suitable for dynamic analysis, the gray here is on behalf of the incomplete information, the correlate analysis overcome the disadvantages and shortcomings of the regression analysis, and avoid the complex process and uncertainty when analytic hierarchy process (ahp) construct judgment matrix.

Scholars based on the different priorities to select suitable statistical methods for their study to quantify the indicators that measure the brand competitiveness in the study, because the set of index is inconsistent and the assessment mode is diversified, the comprehensive index that eventually obtain to measure the brand competitiveness has its own characteristics. But so far, there is not yet a recognized index system, so we need to base on the previous studies to innovate unceasingly, to find a scientific and rational, practical, easy to operate.

\section{CONCLUSION}

Under the market of economy environment, the competition between enterprises has become the performance for the competition of the brand more and more. About how to comment on the size of the corporate brand competitiveness, so as to promote the competitiveness of the corporate brand farther, the Chinese companies have paid close attention to. The research about the corporate brand competitiveness started relatively late in China, the evaluation research about the brand competitiveness is still in the exploratory stage, there is not formed a widely recognized evaluation system, the evaluated methods are mostly using the AHP method and fuzzy mathematics method, AC clustering analysis evaluation method, so the human factors have a big interference to determine the index weight coefficient, also have certain influence on the scientificity and rationality of the evaluation.

\section{CONFLICT OF INTEREST}

The author confirms that this article content has no conflict of interest.

\section{ACKNOWLEDGEMENTS}

Declared none.

\section{REFERENCES}

[1] WANG W, Sun J. The Summarization of Research and Application of Web2. 0. Information Science, 2007, 12: 030.

[2] Na W. Research on the Strategies of Tacit Knowledge Management for Virtual Enterprises in the Web2. 0 Environment. Information Studies: Theory \& Application, 2007, 2: 203-205,240.

[3] Argenti P A, Druckenmiller B. Reputation and the corporate brand Corporate Reputation Review, 2004, 6(4): 368-374. 
[4] Urde M. Core value-based corporate brand building. European Journal of Marketing, 2003, 37(7/8): 1017-1040.

[5] LI J, YU M, WANG Q. The Analysis of Brands Competitiveness. Journal of Shanghai Jiaotong University, 2007, 6: 038.
[6] Jiang L U O. Strategic Measures to Enhance Competitiveness of Brand Journal of Anhui Electric Power College for Staff, 2001, 3: 031.

Received: September 16, 2014

Revised: December 23, 2014

Accepted: December 31, 2014

(C) Liu Biaowen; Licensee Bentham Open.

This is an open access article licensed under the terms of the Creative Commons Attribution Non-Commercial License (http://creativecommons.org/licenses/by-nc/3.0/) which permits unrestricted, non-commercial use, distribution and reproduction in any medium, provided the work is properly cited. 